\title{
The Impact of Public Expenditures on Economic Growth in Jordan
}

\author{
Ali Sulieman Al-Shatti ${ }^{1}$ \\ ${ }^{1}$ Dept. of Banking and Financial Sciences, Philadelphia University, Jordan \\ Correspondence: Ali Sulieman Al-Shatti, Dept. of Banking and Financial Sciences, Philadelphia University, \\ Jordan. E-mail: Alialshati2008@gmail.com
}

Received: May 11, 2014

doi:10.5539/ijef.v6n10p157

\author{
Accepted: July 15, 2014 \\ Online Published: September 25, 2014 \\ URL: http://dx.doi.org/10.5539/ijef.v6n10p157
}

\begin{abstract}
This research aims at examining the impact of the public expenditures on economic growth in Jordan during the time period (1993-2013), by determining the contribution of the current and capital expenditures on Education, Health, Economic Affairs, and Housing and community Utilities as a percent of the total public expenditures, and then examining the impact of each one of them on economic growth in Jordan. Two mathematical models have been designed to measure this impact, the first one measures the impact of current functional expenditures, and the second model measures the impact of capital functional expenditures on economic growth in Jordan. The empirical results show that the impact of current and capital expenditures on education has failed to enhance economic growth, and that is due to the high cost of education, especially higher education in the private sector in Jordan, as well as the growing rate of unemployment, and expenditures on health and economic affairs should be encouraged due to their positive impact on economic growth.
\end{abstract}

Keywords: economic growth, capital expenditures, current expenditures

\section{Introduction}

Examining the impact of public expenditures on economic growth is a crucial step in understanding the sources, the consequences, the future paths of economic growth in Jordan, and in finding the appropriate recommendations to increase the contribution of different productive expenditures in achieving it. Financial policies play an important role in the developing countries. They are considered one of the effective financial tools that affect the public economic activities and the rise of the economic growth rate. Public expenditure is one of the most important tools of the fiscal policy, and especially the capital expenditures which may contribute in the growth of the national economy activities and in achieving the desired economic growth, when they well directed. So Jordan has paid more attention about the importance of the public expenditures in achieving the economic growth.

\subsection{Problem Statement}

The impact of public expenditures on economic growth needs to be studied specially in developing countries, where Jordan is one of them. As these countries share in the suffering from high rates of poverty and unemployment, poor utilization of available resources, and the accelerated rates in budget deficit as a percent of the GDP's of these countries. Consequently, this research seeks to empirically investigate the impact of public spending on economic growth in Jordan during the period (1993-2013). The researcher tries to test the Keynes theory that public expenditures can contribute positively to economic growth and Wagner's law (there is a concurrent grow of per capita income of an economy with the relative size of public expenditure). In an attempt to examine the impact of public expenditures on economic growth in Jordan, the researcher has formulated the following questions:

What is the contribution percent of each one of the four current expenditures (mentioned above) of the total current expenditures?

What is the contribution percent of each one of the four capital expenditures (mentioned above) of the total capital expenditures?

What is the impact of current public expenditure on economic growth in Jordan?

What is the impact of capital public expenditure on economic growth in Jordan?

What are the restrictions that limit the effectiveness of public expenditures in achieving economic growth in 
Jordan?

\subsection{Research Importance}

The purpose of this paper is to examine the impact of public expenditures on economic growth in Jordan during the period 1993-2013, the researcher choose one single country with an attempt to make a more in-depth investigation and analysis, in that it investigates the partial and joint impacts of public expenditure on economic growth in Jordan using certain disaggregated components of government expenditure.

\subsection{Research Objectives}

This research aims to identify the impact of the public expenditures on economic growth in Jordan, by examining the contribution percent of each one of the current and capital expenditures on Education, Health, Economic Affairs, and Housing and Community Utilities of the total public expenditures, and then identifying the impact of each one of them on economic growth in Jordan.

\subsection{Theoretical Literature}

There is a widespread controversy among policymakers about the impact of increased public expenditures on achieving economic growth.

Defenders say that an increase in government spending leads to increasing and improving in the quality of public services provided by the government to their citizens, such as health services, education, housing and social welfare, and also lead to the development of the infrastructure which is necessary to encourage investment, thereby contributing to stimulate economic growth. While opponents say that the increase in government spending leads to expansion of the government size at the expense of the private sector, resulting in conversion of the productive resources in the economy from the efficient productive sectors to the government which is the less efficient sector, with a concomitant increase in the tax rate imposed on the productive sectors to provide sufficient financial fund to meet an increased government demand for money, which in turn reduces the production efficiency in the economy, and thus would hinder the achievement of economic growth. The theories used aim not only to explain the impact of public expenditure on economic growth, but also to find solutions in order to redistribute public expenditures on different productive sectors.

According to the Keynesian macroeconomic theory, public expenditures can contribute positively to economic growth. Hence, an increase in the government consumption is likely to lead to an increase in employment, profitability and investment through multiplier effects on aggregated demand (Urban \& Nordensvard, 2013, p. 71). According to Keynes, government could reverse economic downturns by borrowing money from the private sector and then returning the money to the private sector through various spending programs (Mitchell, 2005).

Wagner's Law: The law predicts that the development of an industrial economy will be accompanied by an increased share of public expenditure in gross national product (Aladejare, 2013). Wagner's law states that, as per capita income of an economy grows, the relative size of public expenditure grows; the relative size of public expenditure grows along with it. As the economy grows, there will be increase in the number of urban centers, with the associated social vices such as; crime, which require the intervention of the government, to reduce such activities to the nearest minimum. Large urban centers also require internal security, to maintain law and order. These interventions by the government have cost, leading to increase in public expenditure in the economy. (Ogba Likita, 1999).

\subsection{Empirical Review}

A number of researches have examined the impact of public expenditures on the economic growth in developed and developing countries like Jordan. The results varied from one research to another.

Abu Al-Foul and Al-Khazali (2003) using data from the Jordanian economy, they conducted a causality test of the Wagner's law which states that there is a relationship between the growth in government expenditures and the economic growth. They found that the growth in the economy granger causes the growth in the government sector. Thus, the Wagner's law applies to the case of Jordan. Using co integration technique and the VAR model, the study suggests that there is auni-directional relationship between the economic growth and the growth of the government expenditures. Bose et al. (2003) examined the growth effects of government expenditure for a panel of thirty developing countries over the decades of the 1970s and 1980s, with a particular focus on sectorial expenditures. They found that the share of government capital expenditure in GDP is positively and significantly correlated with economic growth, but current expenditure is insignificant. Secondly, at the sectorial level, government investment and total expenditures in education are the only outlays that are significantly associated with growth once the budget constraint and omitted variables are taken into consideration. Fanand et al. (2004) 
estimated effects of different types of government expenditure on agricultural growth and rural poverty in Uganda. The results revealed that government spending on agricultural research and extension improved agricultural production substantially. Government spending on rural roads also had substantial marginal impact on rural poverty reduction. Educations effects rank after agricultural research and extension, and roads. Government spending on health did not show a large impact on growth in agricultural productivity or a reduction in rural poverty, but in part because of difficulties in measuring some of the impacts of this type of investment. Kuhar et al. (2005) evaluated impacts of public expenditure on the economic performance of the region Peripheral Slovenia by constructing a regional Input-Output model in the present (2004) and the following (2007) financial perspective. Results showed that the analyzed funds can stimulate a notable economic growth of the Peripheral Slovenia especially in the following financial perspective. However; comparisons of the output growth at the national level reveal likely lagging of the region. This means that the anticipated increase of regional development disparities in Slovenia would continue in the future. Loizides and Vamvoukas (2005) soak to examine if the relative size of government (measured as the share of total expenditure in GNP can be determined to Granger cause the rate of economic growth, or if the rate of economic growth can be determined to Granger cause the relative size of government. Using data on Greece, UK and Ireland, the analysis showed that: 1) government size Granger causes economic growth in all countries of the sample in the short run and in the long run for Ireland and the UK; 2) economic growth Granger causes increases in the relative size of government in Greece, and, when inflation is included, in the UK. Vuale and Suruga (2005) concerned the interaction effect of FDI and public expenditure on economic growth rate, they found there is evidence that excessive spending in public expenditures can hinder the beneficial impact of FDI, they examined also some other potential relationships between FDI and public expenditure and proposed that more efforts should be contributed in building a theoretical model which presents the interrelationship between these factors which contribute in determining the long-term economic growth rate. Abu Tayeh (2009) tried to analyze the factors that affect the Jordanian total government expenditures. This study also employs a specific methodology to assess the natural of the relationship between Jordanian public spending and its determinants. A main result of this research is that population, unemployment and inflation rates are significantly related to the public expenditures. Alexiou (2009) found that four out of the five variables used in the estimation (government spending on capital formation, development assistance, private investment and trade-openness) all have positive and significant effect on economic growth. Population growth in contrast, is found to be statistically insignificant. Al-Zeaud (2009) examined the dynamic import of fiscal policy on the Jordanian economy over the period 1992-2009, using the vector auto regressive (VAR) model, the results showed that one positive structural shock in exports and government spending by \% (or Jordanian dinar) will have positively a significant on real gross domestic product (GDP) in the medium term and long term, also shock in government spending and export result in inflationary pressure in the short term and term. Boustan (2009) found that some investments in education raise growth, and a positive growth effect of exogenous shocks to investments in four-year college education, for all U.S states. But he didn't find that exogenous shocks to investment in two-year college education increase growth. He found that exogenous shocks to research-type education have positive growth effects only in states fairly close to the technological frontier. Abu and Abdullah (2010) investigated the relationship between government expenditure and economic growth in Nigeria by using disaggregated analysis in an attempt to unravel the impact of government expenditure on economic growth. Their results reveal that government total capital expenditure, total recurrent expenditure and Education have negative effect on economic growth. On the contrary, government expenditure on transport, communication and health result in an increase in economic growth. Jafari, Nademi and Zoberi (2010) apply a two-sector production function developed by ram (1986) to estimate the threshold regression model for Islamic countries, regarding the effect of government size on economic growth. The ratio of final government consumption on GDP is used to find out the threshold points. Their empirical results indicate that there is a nonlinear relationship between government size and economic growth in the selected Islamic countries under consideration. Abu Tayeh and Mustafa (2011) their paper aimed at analyzing the factors that affect the Jordanian total government expenditures. They also employed a specific methodology to assess the nature of the relationship between Jordanian public spending and its determinants. A main result of this paper is that population, unemployment and inflation rates are significantly related to the public expenditures. Dauda (2011) examined the effect of government educational spending and macroeconomic uncertainty on schooling outcomes in Nigeria. The study found that public educational spending impacts positively on schooling outcome while macroeconomic instability impacts negatively. Yildirim et al. (2011) studied the effect of government expenditures on economic growth as one of the key issues in economic literature. He performed the causality analysis proposed by Toda and Yamamoto (1995) in order to explore causal relationship between public education expenditures and economic growth in Turkey over the period 
1973-2009. The empirical results showed that the relationship between government expenditures and growth is not in the form of bi-directional causation as causality runs only from economic growth to educational spending but not expenditures on education to economic growth. Nworji et al. (2012), examined the effect of public expenditure on economic in Nigeria for the period 1970-2009. Results of the analysis showed that capital and recurrent expenditure on economic services had insignificant negative effect on economic growth during the study period. Also, capital expenditure on transfers had insignificant positive effect on growth. But capital and recurrent expenditures on social and community services and recurrent expenditure on transfers had significant positive effect on economic growth. Olabisi (2012) explored the relationship between the composition of public expenditure and economic growth in Nigeria. He found that expenditure on education has failed to enhance economic growth due to the high rate of rent seeking in the country as well as the growing rate of unemployment. They also noted that expenditure on health and agriculture should be encouraged due to their positive contributions to growth. Patricia (2013) investigated the effects of public expenditure in education on economic growth in Nigeria over a period from 1977 to 2012, with particular focus on disaggregated and sectorial expenditures analysis. They found that Total Expenditure on Education is highly and statistically significant and have positive relationship on economic growth in Nigeria in the long run.

This study improves on some of the existing studies, in that it investigates the partial and joint effects of public expenditure on economic growth in Jordan using certain disaggregated components of public expenditure. It also contributes to the existing literature on the long run impact of public expenditure on economic growth in Jordan. However, the study excludes administrative expenditure in that it is included in current expenditures and the other nonproductive expenses.

\subsection{Jordan's Economy}

Jordan's economy is among the smallest in the Middle East, with insufficient supplies of water, oil, and other natural resources underlying the government's heavy reliance on foreign assistance. Other economic challenges for the government include chronic high rates of poverty, unemployment, inflation, and a large budget deficit. Since assuming the throne in 1999, King ABDALLAH has implemented significant economic reforms, such as opening the trade regime, privatizing state-owned companies, and eliminating some fuel subsidies, which in the last decade spurred economic growth by attracting foreign investment and creating some jobs. The global economic slowdown and regional turmoil, however, have depressed Jordan's GDP growth, impacting export-oriented sectors, construction, and tourism. In 2011 and 2012, the government approved two economic relief packages and a budgetary supplement, meant to improve the living conditions for the middle and poor classes. Jordan's finances have also been strained by a series of natural gas pipeline attacks in Egypt, causing Jordan to substitute more expensive diesel imports, primarily from Saudi Arabia, to generate electricity. Jordan is currently exploring nuclear power generation in addition to the exploitation of abundant oil shale reserves and renewable technologies to forestall energy shortfalls. In 2012, to correct budgetary and balance of payments imbalances, Jordan entered into a $\$ 2.1$ billion, multiple years International Monetary Fund Stand-By Arrangement. Jordan's financial sector has been relatively isolated from the international financial crisis because of its limited exposure to overseas capital markets. In 2013, Jordan depended heavily on foreign assistance to finance the budget deficit, as the influx of about 600,000 Syrian refugees put additional pressure on expenditures (indexmundi).

\subsection{Research Hypotheses}

This research is based on two main hypotheses:

Hypothesis one:

$\mathrm{H}_{0} 1$ : Current public expenditure has no significant impact on economic growth.

And it is branching off sub- hypotheses as follows:

1). Current public expenditure on education has no significant impact on economic growth.

2). Current public expenditure on health has no significant impact on economic growth.

3). Current public expenditure on economic affairs has no significant impact on economic growth.

4). Current public expenditure on housing and community facilities has no significant impact on economic growth.

Hypothesis two:

$\mathrm{H}_{0}$ 2: Capital public expenditure has no significant impact on economic growth. 
And we branch off the following sub- hypotheses:

1). Capital public expenditure on education has no significant impact on economic growth.

2). Capital public expenditure on health has no significant impact on economic growth.

3). Capital public expenditure on economic affairs has no significant impact on economic growth.

4). Capital public expenditure on housing and community facilities has no significant impact on economic growth.

\subsection{Research Design}

The research is organized as follows: Part one presents the introduction and an extensive review of literature on the impact of public expenditures on economic growth. Part two spells out the methodological approaches used in this research. Where part three focuses on the analysis of the research hypotheses, and to show the contribution of research results in the provision of a new addition to previous studies. Lastly, part four suggests the significance of these results for decision makers in Jordan, and the proposed recommendations by the researcher.

\section{Method}

\subsection{Data}

This research attempts to examine the impact of public expenditures on economic growth in Jordan during the period (1993-2013) using for this purpose statistical techniques: sources of data: the study is based on the annual reports of central bank of Jordan, General budget department, Department of Statistics.

\subsection{Model Specification}

The following two models represent the impact of public expenditures on the economic growth, as follows:

$$
\begin{aligned}
& \text { Ln } R G D P=a 0+L n a l C R L+L n a 2 C R H+L n a 3 C R E+L n a 4 C R S \\
& \text { Ln } R G D P=b 0+\text { Ln blCAL + Ln b2CAH+Ln b3CAE + Ln b4CAS }
\end{aligned}
$$

The model number (1) measures the impact of the current expenditures on education, health, economic affairs, and housing and community facilities (CRL, CRH, CRE and CRS) respectively, on economic growth (real GDP). By calculating the Ln of these variables.

The 2nd model measures the impact of the capital expenditures on education, health, economic affairs, and housing and community facilities (CAL, CAH, CAE and CAS) respectively, on economic growth (real GDP). By calculating the $\mathrm{Ln}$ of these variables. Where (a0, a1, a2, a3, a4) coefficients of the components of current public expenditures, and (b0, b1, b2, b3, b4) coefficients of the components of capital public expenditures, which measure the impact of the respective components of public expenditures on economic growth.

\subsection{Research Variables Definition}

Table 1. Variables definition

\begin{tabular}{lll}
\hline variables symbols & Variables explanations & Measurement unit \\
\hline RGDP & Real GDP & Ln RGDP \\
CRL & current expenditure on education & Ln CRL \\
CRH & current expenditure on health & Ln CRH \\
CRE & current expenditure on economic affairs & Ln CRE \\
CRS & current expenditure on housing and community facilities & Ln CRS \\
ao,a1,a2,a3,a4 & $1^{\text {st }}$ model coefficients & \\
CAL & capital spending on education & Ln CAL \\
CAH & capital spending on health & Ln CAH \\
CAE & capital expenditure on economic affairs & Ln CAE \\
CAS & capital spending on housing and social facilities & Ln CAS \\
bo,b1,b2,b3,b4 & $2^{\text {nd }}$ model coefficients & \\
\hline
\end{tabular}

Source: Author computation.

Where:

RGDP: Represent the Jordanian real gross domestic product during the period (1993-2013).

CRL: Represent current spending on education which includes expenses on pre- primary and primary education, 
secondary education, higher education, education without a specified level, assistance services for education.

CRH: Represent current spending on health services, which includes expenses on health products and medical devices and equipment, Outpatient services, Hospital services, Public health services, Research and development in the health field, Public health affairs classified elsewhere.

CRE: Represent current spending on economic affairs which includes expenses on economic \& business affairs and public employment, agriculture, forestry, fishing and hunting, fuel and energy, mining, manufacturing and construction, transportation, communications, other industries, economic affairs classified elsewhere.

CRS: Represent current spending on current expenditure on housing and community facilities, which include expenses on community development, water supply, housing and community facilities not classified elsewhere.

CAL: Represent capital spending on education which includes expenses on pre- primary and primary education, secondary education, higher education, education without a specified level, assistance services for education.

CAH: Represent capital spending on health services, which includes expenses on health products and medical devices and equipment, Outpatient services, Hospital services, Public health services, Research and development in the health field, Public health affairs classified elsewhere.

CAE: Represent capital spending on economic affairs which includes expenses on economic \& business affairs and public employment, agriculture, forestry, fishing and hunting, fuel and energy, mining, manufacturing and construction, transportation, communications, other industries, economic affairs classified elsewhere.

CAS: Represent capital spending on current expenditure on housing and community facilities, which includes expenses on community development, water supply, housing and community facilities not classified elsewhere.

\subsection{Data Analysis}

This research applies the descriptive and econometrics analysis approach in examining the impact of public expenditures on economic growth in Jordan during the time period (1993-2013), and so that we use the multiple regression method, which is being estimated by the least squares method (OLS), through applying the statistical program (E -Views) on the time series data relating to components of public expenditures and real GDP during the period of the study, from the annual accounts issued by the General Budget Department, and the Department of Statistics, and the relevant previous studies conducted on Jordan and other countries around the world. Where the research tries to determine the partial and joint impact of public expenditures on economic growth in Jordan.

\subsection{Percentage Distribution of Current and Capital Expenditures}

As shown in the table No. (2) the percentage share of the current expenses components, (education, health, economic affairs, housing and community facilities) which form $(98.89 \%)$ of the total current expenditures during the study period, means that most of the current functional expenditures dedicated to be spent on these main four components. The current expenditure on education is $(80.44 \%)$, followed by the current expenditure on health forms (13.71\%), then the current expenditure on economic affairs by $(2.14 \%)$, and finally the current expenditure on housing and community facilities by $(0.61 \%)$ of the total current expenditures.

Table 2. Percentage distribution of current expenditures

\begin{tabular}{lllllll}
\hline Year & Total current exp. & Current exp. \% & Education \% & Health \% & Economic \% & Housing \% \\
\hline 1993 & 1044.29 & 0.7813 & 0.1208 & 0.0550 & 0.0410 & 0.0092 \\
1994 & 1115.16 & 0.7786 & 0.1373 & 0.0083 & 0.0425 & 0.0098 \\
1995 & 1220.44 & 0.7604 & 0.1440 & 0.0100 & 0.0417 & 0.0098 \\
1996 & 1296.63 & 0.7598 & 0.1491 & 0.0099 & 0.0177 & 0.0097 \\
1997 & 1438.00 & 0.8122 & 0.1418 & 0.0083 & 0.0158 & 0.0090 \\
1998 & 1620.53 & 0.7873 & 0.1267 & 0.0077 & 0.0145 & 0.0084 \\
1999 & 1643.10 & 0.8056 & 0.1595 & 0.0298 & 0.0196 & 0.0037 \\
2000 & 1851.30 & 0.8465 & 0.1490 & 0.0215 & 0.0199 & 0.0035 \\
2001 & 1851.30 & 0.8209 & 0.1560 & 0.0297 & 0.0256 & 0.0037 \\
2002 & 1899.90 & 0.7929 & 0.1624 & 0.0167 & 0.0232 & 0.0040 \\
2003 & 2163.70 & 0.7701 & 0.1543 & 0.0111 & 0.0176 & 0.0044 \\
2004 & 2377.80 & 0.7476 & 0.1497 & 0.0307 & 0.0189 & 0.0013 \\
2005 & 2908.00 & 0.8217 & 0.1320 & 0.0236 & 0.0158 & 0.0010 \\
2006 & 3118.10 & 0.7970 & 0.1318 & 0.0326 & 0.0151 & 0.0011 \\
\hline
\end{tabular}




\begin{tabular}{lllllll}
\hline 2007 & 3743.90 & 0.8163 & 0.1302 & 0.0294 & 0.0129 & 0.0010 \\
2008 & 4473.40 & 0.8235 & 0.1137 & 0.0183 & 0.0148 & 0.0038 \\
2009 & 4586.60 & 0.7605 & 0.1131 & 0.0232 & 0.0171 & 0.0038 \\
2010 & 4746.60 & 0.8316 & 0.1215 & 0.0133 & 0.0220 & 0.0195 \\
2011 & 5739.50 & 0.8445 & 0.1192 & 0.0143 & 0.0193 & 0.0160 \\
2012 & 6202.80 & 0.9018 & 0.1263 & 0.0082 & 0.0173 & 0.0028 \\
2013 & 6210.10 & 0.8329 & 0.1416 & 0.0164 & 0.0180 & 0.0031 \\
Average & & 0.8044 & 0.1371 & 0.0199 & 0.0214 & 0.0061 \\
\multicolumn{2}{l}{ Percentage of 4 sectors } & 0.9889 & & & & \\
\hline
\end{tabular}

Source: Author computation.

And as shown in the table No. (3). The percentages share of capital public expenditure on education, health, economic affairs, housing and community facilities form $(67.56 \%)$ of the total capital expenditures during the years of the study, which is acceptable to some extent, but when compared to the percentage share of current expenditures which account for $(98.89 \%)$, seems low. And the percentages share of the components of capital public expenditure, as follows: on education is $(7.66 \%)$ represents the lowest percentage among the four components, and on health is $(10.29 \%)$, as well as spending on economic Affairs won the highest rate which reached $(33.36 \%)$, and finally spending on housing and community facilities reached $(16.25 \%)$ of the total capital expenditures.

Table 3. Percentage distribution of capital expenditures

\begin{tabular}{lccccc}
\hline Year & Total capital exp. & Education \% & Health \% & Economic. \% & Housing \% \\
\hline 1993 & 292.29 & 0.0549 & 0.0473 & 0.4592 & 0.1858 \\
1994 & 317.05 & 0.0292 & 0.0371 & 0.4795 & 0.2266 \\
1995 & 384.50 & 0.0317 & 0.0360 & 0.4201 & 0.2106 \\
1996 & 410.00 & 0.0313 & 0.0434 & 0.4392 & 0.2079 \\
1997 & 332.48 & 0.0357 & 0.0772 & 0.2920 & 0.2413 \\
1998 & 437.68 & 0.0286 & 0.0690 & 0.2444 & 0.1622 \\
1999 & 396.40 & 0.1234 & 0.1163 & 0.2460 & 0.2896 \\
2000 & 335.80 & 0.1185 & 0.1176 & 0.2513 & 0.2162 \\
2001 & 403.80 & 0.1362 & 0.1206 & 0.1914 & 0.1751 \\
2002 & 496.30 & 0.0639 & 0.1068 & 0.1783 & 0.1352 \\
2003 & 646.10 & 0.0373 & 0.0814 & 0.1501 & 0.1076 \\
2004 & 802.70 & 0.0909 & 0.0771 & 0.2975 & 0.0348 \\
2005 & 630.90 & 0.1086 & 0.0802 & 0.3761 & 0.0338 \\
2006 & 794.10 & 0.1281 & 0.1395 & 0.3517 & 0.0307 \\
2007 & 842.60 & 0.1305 & 0.1373 & 0.3265 & 0.0395 \\
2008 & 958.50 & 0.0854 & 0.1451 & 0.3820 & 0.1584 \\
2009 & 1444.50 & 0.0737 & 0.1603 & 0.3283 & 0.1898 \\
2010 & 961.40 & 0.0657 & 0.1536 & 0.3650 & 0.1756 \\
2011 & 1057.10 & 0.0777 & 0.1447 & 0.3879 & 0.1515 \\
2012 & 675.40 & 0.0751 & 0.1538 & 0.4942 & 0.2233 \\
2013 & 1245.60 & 0.0816 & 0.1183 & 0.3449 & 0.2182 \\
Average & 0.0065 & 0.0766 & 0.1029 & 0.3336 & 0.1625 \\
\hline
\end{tabular}

Source: Author computation.

\subsection{Statistical Analysis and Interpretation}

- Unit Root Test Results (Model No. 1)

Stationary of the expletory variables and dependent variable for the model number 1, (Ln RGDP) was tested using Augmented Dickey Fuller (ADF) test. Table (4) views the results which indicate the rejection of the unit root null hypothesis of the stationary of the Ln of (CRL, CRH, CRE, CRS) and Ln RGDP at the first difference. 
Table 4. Unit stationary test of current expenditures variables

\begin{tabular}{cccc}
\hline Variables & ADF Statistics & P- Value & Order of Integration \\
\hline Ln RGDP & -4.180356 & 0.0048 & I (1) \\
Ln CRL & -4.815919 & 0.0013 & I (1) \\
Ln CRH & -4.713782 & 0.0016 & I (1) \\
Ln CRE & -3.581716 & 0.0182 & I (1) \\
Ln CRS & -3.848775 & 0.0115 & I (1) \\
\hline
\end{tabular}

Source: Author computation from computer output.

\section{- $\quad$ Unit Root Test Results (Model No. 2)}

Stationary of the expletory variables and dependent variable for the model number 2, (Ln RGDP) was tested using Augmented Dickey Fuller (ADF) test. Table (5) views the results which indicate that the rejection of the unit root null hypothesis of stationary of the Ln of (CAL, CAH, CAE, CAS) and Ln RGDP at the first difference.

Table 5. Unit stationary test of capital expenditures variables

\begin{tabular}{cccc}
\hline Variables & ADF Statistics & P- Value & Order of Integration \\
\hline Ln RGDP & -6.463527 & 0.0001 & $\mathrm{I}(1)$ \\
Ln CAL & -3.255322 & 0.0366 & $\mathrm{I}(1)$ \\
Ln CAH & -5.085001 & 0.0009 & $\mathrm{I}(1)$ \\
Ln CAE & -8.44948 & 0.0000 & $\mathrm{I}(1)$ \\
Ln CAS & -5.046358 & 0.0009 & $\mathrm{I}(1)$ \\
\hline
\end{tabular}

Source: Author computation from computer output.

\section{Results}

This research aims at examining the impact of the public expenditures on economic growth in Jordan during the time period (1993-2013). On average, Jordan's public current expenditure exceeded the public capital expenditure during the study period (1993-2013). This is considered preposterous, where Jordan as a developing country should spend more on capital structure to increase the growth rate of its economy.

The researcher found that there is a statistically significant impact of the current expenses paid on health, economic affairs, and housing and community facilities and of the capital expenditures on health and economic affairs on economic growth in Jordan, and there is no statistically significant impact of the current expenses on education and of the capital expenditures on education, housing and community facilities on economic growth in Jordan.

This is contrary to the of Akpan's (2005) submission of no significant relationship between economic growth and most of the components of government expenditure and Olopade and Olepade (2010) who found that no significant relationship between most of the components of expenditure and economic growth, but in agreement with Ogiogio (1995) who submitted that current expenditure exacted more significant effect than capital expenditure, and Abu Al-Foul and Al-Khazali (2003), who found that the growth in the economy granger causes the growth in the government sector in Jordan and with Dandan (1011) who found that the government expenditure at the aggregate level has positive impact on the growth of GDP which is compatible with the Keynesian's theory.

The joint effect of these components of (current and capital) public expenditures on economic growth is statistically significant as indicated by the computed F-Statistic and its probability. Therefore, the study submits that there is an impact of public expenditures on economic growth, and that the current expenditure exerts significant impact on the capital expenditure. Result of the analysis also shows that the explanatory variables included in the 1st model explain about $98 \%$, and in the 2nd model explain about $93 \%$ variations in the explained variable. This high explanatory power shows that the two models are a good fit, and that these components of public expenditures are important determinants of economic growth in Jordan.

\section{Discussions}

The study further concludes that the components of public expenditures considered in this study are important variables in explaining economic growth in Jordan. Based on findings from the empirical analysis, the study 
offers the following recommendations, among others:

Capital and current expenditures on economic affairs should be directed mainly to productive economic activities. This will stimulate activities in the economic sectors and, perhaps, reverse the negative effect of them on economic growth, and the proportion of total public expenditures that goes into funding some components of capital and current expenditure should be increased since these components exert significant positive effect on economic.

These results insure that the need to develop awareness among different social groups related economic sectors and activities to encourage their involvement in the available opportunities.

\section{References}

Abu Tayeh, S. (2004). The Determinants of Public Expenditures in Developing Countries: Evidence from Jordan (1981-2001). A paper presented in the 11th Annual Conference of American Society of Business and Behavioral Sciences, Las Vegas.

Abu, N., \& Abdulahi, U. (2010). Government Expenditure and Economic Growth in Nigeria, 1970-2008: A Disaggregated Analysis. Business and Economic Journal, 4(3), 237-330.

Al Bataineh, I. M. (2012). The impact of government expenditures on economic growth in Jordan. Interdisciplinary Journal of Contemporary Research in Business, 4(6).

Aladejare, S. A. (2013). Government Spending and Economic Growth: Evidence from Nigeria. Munich Personal RePEc Archive (MPRA). Retrieved from http://mpra.ub.uni-muenchen.de

Alexandru, M. (2008). The Role of Public Spending in the Growth Theory Evolution. Romanian Journal of Economic Forecasting.

Alexiou, C. (2009). Government Spending and Economic Growth: Econometric Evidence from the South Eastern Europe. Journal of Economic and Social Research, 11(1), 1-16.

Andreas, I., \& Johanna, K. (2008). Productive Government Expenditure and Economic Growth. Discussion paper Series No. 464. Retrieved from http://www.uni-heidelberg.de/md/awi/forschung/dp464.pdf

Asghar, N., Azim, P., \& Rehman, H. (2011). Impact of Government Spending in Social Sectors on Economic Growth: A Case Study of Pakistan. Journal of Business \& Economics, 3(2), 214-234.

Butkiewicz, J. M., \& Yanikkaya, H. (2011). Institutions and the impact of government spending on growth. Journal of Applied Economics, XIV(2). http://dx.doi.org/10.1016/S1514-0326(11)60017-2

Chude, N. P., \& Chude, D. I. (2013). Impact of government expenditure on economic growth in Nigeria. International Journal of Business and Management Review, 1(4), 64-71.

Dandan, M. (2011). Government expenditures and economic growth in Jordan. International Conference on Economics and Finance Research IPEDR, 4.

Dauda, R. S. (2011). Effect of public educational spending and Macroeconomic Uncertainty on schooling outcomes: evidence from Nigeria. Journal of Economics, Finance and Administrative Science, 16(31).

Jegede, C. A. (2013). The Nexus between Government Expenditure and Economic Growth of a Developing Economy. International Journal of Research in Business and Technology, 3(1).

Jordan Department of Statistics. (1993-2013). Annual reports.

Jordan's Economy Profile. (n.d.). Retrieved from http://www.indexmundi.com/jordan/economy_profile.html

Junko, K., \& Vitali, K. (2008). Impact of Government Expenditure on Growth: The Case of Azerbaijan. Working paper, International Monetary Fund.

Keynes, J. M. (1936). The General Theory of Employment, Interest and Money (1936). In J. M. Keynes (Ed.), The General Theory (Vol. 7). London: Macmillan for the Royal Economic Society. Retrieved on February 2, 2005, from http://acepa.newschool.edu/het/essays/Keynes/gtcont.htm

Kuhar, A., Juvancic, L., Sila, U., \& Erjavec, E. (2005). Evaluation of public expenditure on economic growth of the peripheral Slovenia with input-output model. Acta Agriculturae Slovenica, 1, 49-61.

Lewis, C. W., \& Hildreth, W. B. (2012). Using the gross domestic product to measure the role and size of government Budgeting: Politics and Power (2nd ed.). New York.

Liutang, G., \& Heng-fu, Z. (2002). Effects of Growth and Volatility in Public Expenditures on Economic Growth: Theory and Evidence. Annals of Economics and Finance, 3, 379-406. 
Loizides, J., \& Vamvoukas, G. (2005). Government expenditure and economic growth: Evidence from trivariate causality testing. Journal of Applied Economics, VIII(1), 125-152.

Matthew, A., James, S., \& Sehilat, A. (2012). Fiscal/Monetary Policy and Economic Growth in Nigeria. International Journal of Academic Research in Economics and Management Sciences, 1(5).

Mitchell, D. J. (2005). The Impact of Government Spending on Economic Growth. Heritage Foundation Backgrounder No. 1831. Retrieved from http://www.heritage.org/research/reports

Monteiro, G., \& Turnovsky, S. I. (2008). The composition of productive government expenditure: Consequences for economic growth and welfare. Indian Growth and Development Review, 1(1), 57-83. http://dx.doi.org/10.1108/17538250810868134

Niloy, B. M., Emranul, H., \& Denise, R. O. (2007). Public Expenditure and Economic Growth. The Manchester School, 75(5).

Nkiru, P., \& Daniel, I. (2013). Impact of government expenditure on economic growth in Nigeria. International Journal of Business and Management Review, 1(4), 64-71.

Nurtac, Y., Hulya, D., \& Aycan, H. D. (2011). Public Education Expenditures Really Lead to Economic Growth? Evidence from Turkey. International Research Journal of Finance and Economics, 65.

Nworji, I. D., Okwu, A. T., Obiwuru, T. C., \& Nworji, L. O. (2012). Effects of public expenditure on economic growth in Nigeria. International Journal of Management Sciences and Business Research, 1(7).

Ogba Likta, (1999). Elements of public finance. T.O.Abayomi industrial packaging ltd, Agege.

Shenggen, F., Xiaobo, Z., \& Neetha, R. (2004). Public expenditure, growth, and poverty reduction in rural Uganda: development Strategy and Governance Division. International Food Policy Research Institute, Washington, D.C. Retrieved from https://www.google.jo/url

Urban, F., \& Nordensvard, J. (2013). Low Carbon Development: Key Issues in Environment and Sustainability. USA: Routledge. Retrieved from https://books.google.jo

\section{Appendix A}

Functional classification summary of public expenditures classified by departments and functional groups

\begin{tabular}{|c|c|c|c|c|c|c|}
\hline $\begin{array}{l}\text { Zip } \\
\text { Code } \\
\end{array}$ & $\begin{array}{l}\text { Functional } \\
\text { Section }\end{array}$ & $\begin{array}{l}\text { Functional } \\
\text { Code }\end{array}$ & Functional Group & $\begin{array}{l}\text { Current } \\
\text { Expenses }\end{array}$ & $\begin{array}{l}\text { Capital } \\
\text { Expenses }\end{array}$ & $\begin{array}{l}\text { Total } \\
\text { Expenses }\end{array}$ \\
\hline \multirow[t]{8}{*}{704} & Economic & 7041 & Economic \& Business affairs and public employment & & & \\
\hline & Affairs & 7042 & Agriculture, forestry, fishing and hunting & & & \\
\hline & & 7043 & Fuel and Energy & & & \\
\hline & & 7044 & mining, manufacturing and construction & & & \\
\hline & & 7045 & Transportation & & & \\
\hline & & 7046 & Communications & & & \\
\hline & & 7047 & Other Industries & & & \\
\hline & & 7048 & Economic Affairs classified elsewhere & & & \\
\hline \multirow[t]{3}{*}{706} & Housing and & 7062 & Community Development & & & \\
\hline & community & 7063 & Water supply & & & \\
\hline & facilities & 7066 & Housing and community facilities not classified elsewhere & & & \\
\hline \multirow[t]{6}{*}{707} & Health & 7071 & health products and medical devices and equipment & & & \\
\hline & & 7072 & Outpatient services & & & \\
\hline & & 7073 & Hospital services & & & \\
\hline & & 7074 & Public health services & & & \\
\hline & & 7075 & Research and development in the health field & & & \\
\hline & & 7076 & Public health affairs classified elsewhere & & & \\
\hline \multirow[t]{5}{*}{709} & Education & 7091 & Education pre- primary and primary education & & & \\
\hline & & 7092 & Secondary education & & & \\
\hline & & 7094 & Higher education & & & \\
\hline & & 7095 & Education without a specified level & & & \\
\hline & & 7096 & Assistance services for education & & & \\
\hline
\end{tabular}

Source: Department of the general budget, a draft of Jordanian budget for the year 2014. 


\section{Copyrights}

Copyright for this article is retained by the author(s), with first publication rights granted to the journal.

This is an open-access article distributed under the terms and conditions of the Creative Commons Attribution license (http://creativecommons.org/licenses/by/3.0/). 